\title{
Pre-Screening at the Border in the Asylum and Migration Pact: A Paradigm Shift for Asylum, Return and Detention Policies?
}

\author{
Lyra Jakulevičiene*
}

The New Pact on Migration and Asylum ${ }^{1}$ announced by the European Commission on 23 of September 2020 contains a new piece of legislation: a Proposal for a Regulation introducing a screening of third country nationals at the external borders and amending some related regulations ${ }^{2}$ (hereafter Proposal for a Screening Regulation, Proposal). From the first outlook it seems that a novelty - a pre-entry screening - procedure is introduced. A more thorough analysis raises several questions. Firstly, is this novelty really new, and if not, is it worthwhile investing almost 0.5 billion euros in re-decorating old practices that did not work? Second, will the measures proposed be adequate to address the challenges and meet the objectives indicated, or will they raise more legal and practical issues than the existing ones? Last, but not least, how realistic are such provisions to be implemented once adopted?

\section{Novelties of the Proposal or Re-Decoration of Existing Practices?}

The objective of the Proposal for a Screening Regulation is two-fold: a) to identify the persons, establish health and security risks at soonest; and b) to direct the persons to relevant procedures, be it either asylum or return (Art. 1). If compared with the current obligations of European Union (hereafter EU) Member States at the borders, it is evident that identity, registration and security checks, as well as preliminary vulnerability assess-

* Prof. Dr. at the Mykolas Romeris University, Lithuania.

1 Commission, 'Communication on a New Pact on Migration and Asylum' $\operatorname{COM}(2020) 609$ of 23 September 2020.

2 Commission, 'Proposal for a Regulation introducing a screening of third country nationals at the external borders' $\operatorname{COM(2020)612~of~} 23$ September 2020. 
ments are happening anyway on the basis of the Schengen Borders Code ${ }^{3}$ and the national legislation. While the Schengen Borders Code does not provide for any specific obligations concerning medical checks of third country nationals apprehended during border surveillance, health checks have been recently introduced by the Member States in response to the COVID-19 pandemic. With regard to medical checks the Proposal is making such checks mandatory for all third country nationals apprehended during border surveillance or disembarked following a search and rescue operation, although in practice the Member States already carry out such health checks. ${ }^{4}$ Thus many elements included in the Proposal correspond largely to what border authorities are already requested to do under the existing legislative framework.

What might be new indeed is the projected outcome of such screening procedure and its implications for the entire asylum and return process, and the individuals concerned. The Commission has justified the proposal with the need to "streamline" procedures "upon arrival". ${ }^{5}$ This reflects on national trends post-2015 in some of the Member States to shift towards a more process-oriented approach, whereby, for example, rather than viewing return as a distinct procedure that starts after the asylum procedure has finished, several Member States are moving towards a model in which tasks and steps are taken across the continuum between registration and possible return. ${ }^{6}$ The Proposal envisages that the outcome of the screening will be direction of the persons to appropriate procedures - either asylum procedures or returns and also it will impact on whether to channel asylum seekers to border or regular asylum procedures. It will be discussed below to what extent this is a novelty and whether it raises legal questions.

Pre-screening procedures are not new as such. They are employed, for instance, in Australia (so-called 'enhanced screening process', which 'screens in' to the refugee status determination and complementary protection system), although they have been criticized as risking to exclude those with legitimate claims for protection due to too short interviews, absence of legal advice, lack of written record of the proceedings and

3 Regulation (EU) 2016/399 of the European Parliament and of the Council of 9 March 2016 on a Union Code on the rules governing the movement of persons across borders (Schengen Borders Code) [2016] OJ L 77/1.

4 European Parliament, 'The European Commission's legislative proposals in the New Pact on Migration and Asylum' (Study, July 2021), 53.

5 Ibid 52.

6 Hanne Beirens, 'Chasing Efficiency: Can operational changes fix European asylum systems?' (Migration Policy Institute, February 2020), 53. 
other setbacks. ${ }^{7}$ Similar swift identification, registration and fingerprinting experiences were in the hotspots in Greece and Italy established in the aftermath of the 2015-2016 migration 'crisis' in Europe and the Proposal could be seen as an adaptation and generalisation of the border control practices under this 'hotspot approach', ${ }^{8}$ which, according to Maiani, have failed to produce any tangible results. ${ }^{9}$ As Evaluation of the Proposal concludes, the Proposal does not address the main bottlenecks of this approach as identified by existing evaluations and scholarly research on its implementation, ${ }^{10}$ but rather further reinforces these. ${ }^{11}$ Will the pre-entry screening in the EU result in a different outcome?

\section{Are Asylum Seekers no Longer a Privileged Group of Migrants in Europe?}

The screening procedure under the Proposal for a Screening Regulation would apply to three groups of persons: migrants who have entered in unauthorised manner, asylum seekers who entered without authorisation and persons disembarked after a search and rescue operation (Art. 3 and 5). During the screening process these persons would not be considered as being authorised entry into the Member State territory (Art. 4(1)). What is particularly striking in the proposal is the elimination of a fine line that exists in international and EU law between persons seeking international protection and other migrants, as all of them will undergo the same proce-

7 Australian Human Rights Commission (June 2013) <https://humanrights.gov.au /sites/default/files/document/publication/enhanced-screening.pdf $>$ accessed 12 September 2021.

8 European Parliament, 'The European Commission's legislative proposals in the New Pact on Migration and Asylum' (n 4), 48.

9 Francesco Maiani, 'Hotspots and Relocation Schemes: the right therapy for the Common European Asylum System?' (EU Migration Law Blog, 3 February 2016) $<$ https://eumigrationlawblog.eu/hotspots-and-relocation-schemes-the-right-therap y-for-the-common-european-asylum-system/> accessed 29 October 2021.

10 European Council for Refugees and Exiles, 'The implementation of the hotspots in Italy and Greece. A Study' (2017); EU Agency for Fundamental Rights, 'Update of the 2016 Opinion of the European Union Agency for Fundamental Rights on fundamental rights in the "hotspots" set up in Greece and Italy' (2019); Elisa Pascucci and Emma Patchett, 'Hotspots: Questioning the Future of Europe through Its Borders' (2018) 14 (4) Journal of Contemporary European Research 324, recited from European Parliament, 'The European Commission's legislative proposals in the New Pact on Migration and Asylum' (n 4), 53.

11 European Parliament, 'The European Commission's legislative proposals in the New Pact on Migration and Asylum' (n 4), 53. 
dure. This differentiation follows a legal rationale, as persons who seek protection are subject to special treatment with regard to entry and stay in the host country as confirmed by the existence of a special international instrument - the 1951 United Nations (hereafter UN) Convention Relating to the Status of Refugees ${ }^{12}$ and recognition of asylum seekers in the European Court of Human Rights (hereafter ECtHR) jurisprudence as particularly vulnerable category of migrants in need of special protection. ${ }^{13}$

In contrast to that legal distinction, the Proposal builds on the premise that asylum seekers and migrants are the same category of unauthorised entrants and disregards the fact that asylum seekers' need for protection overrides the entry requirements, as confirmed by Art. 6(5)(c) of the Schengen Borders Code, non-application of responsibility to illegal entry as per Art. 31 of the 1951 Geneva Convention and ample jurisprudence of the European courts. Other migrants under international and EU law do not have the same rights of entry or special treatment as protection seekers even though they are protected under general human rights instruments. The proposal blurs up this distinction by placing both groups of persons under the same legal regime instead of clearly differentiating them, as their chances to stay in the EU are very different. This approach does not in itself violate the mentioned obligations, as long as persons are directed to an asylum procedure. But it could overall promote stereotypes that asylum seekers and irregular migrants are the same and could lead to wrong practices whereby protection seekers are treated by the border guard authorities in the same way as other migrants who arrive in an unauthorised way disregarding their protection needs.

This is reinforced by retaining a certain level of ambiguity in the proposal as to the relationship of the screening procedure with derogation from entry requirements for asylum seekers under Art.6(5)(c) of the Schengen Borders Code (reference to international obligations). The Proposal mentions exclusion from the screening of persons authorised entry under this derogation by an individual decision (Recital 14) but then includes them into screening under Art. 3(2). The Presidency compromise proposal presented in May 2021 further refers to this situation by including also third country nationals who make an application for international protection and benefit from an authorisation to enter on humanitarian

12 United Nations, Treaty Series (189) 137.

13 M.S.S. $v$ Belgium and Greece App no 30696/09 (ECtHR, 21 January 2011); Tarakbel $v$ Switzerland App no 29217/12 (ECtHR, 4 November 2014); A.S. $v$ Switzerland App no 39350/13 (ECtHR, 30 June 2015). 
grounds or international obligations under Art. 6(5)(c) of Regulation (EU) 2016/399. ${ }^{14}$ If understood in this way, the Proposal would then also include asylum seekers whose entry is authorised, not only those arriving in an irregular manner, thereby depriving the recital 14 of the Proposal of its meaning. In addition, this relationship would be clearer if the Proposal would specifically exclude those persons from screening who are manifestly in need of international protection as per international obligations of the Member States (e.g. nationalities over 50\% for recognition for international protection), while conducting screening for all others where such needs are not so clear.

\section{Potential Legal Problems of the Proposed Measures}

Further we will explore whether the measures proposed are adequate to address the challenges and meet the objectives indicated, or will raise more legal and practical issues than the existing ones?

\section{a) Mere Information Gathering that Substantially Affects the Status and Rights of the Person?}

The Proposal for a Screening Regulation envisages that the screening ends with a de-briefing form completed by the authorities responsible for screening, to be transmitted to asylum or return authorities respectively (Art. 14(1)). In this form they should indicate any elements that might be relevant for determining the submission of persons to border or accelerated examination procedures (Art. 14(2)). There is a possibility also that the person is not referred to any procedures, but is refused entry (Art. 14(1)). The amended proposal for Asylum Procedures Regulation $2020^{15}$ confirms these three outcomes of the screening (recital 40): a) channelling of the applicant to the appropriate asylum procedure, b) return procedure or c) refusal of entry.

14 Presidency compromise proposal, recital 2, Brussels (17 May 2021) <www.statew atch.org/media/2436/eu-council-screening-regulation-compromise-8814-21.pdf $>$ accessed 30 October 2021.

15 Amended Proposal for a Regulation establishing a common procedure for international protection in the Union and repealing Directive 2013/32/EU, $\operatorname{COM}(2020) 611$ of 23 September 2020. 
Although it is claimed that screening as such is a mere information gathering, which does not entail any decision affecting the rights of the person concerned, ${ }^{16}$ the analysis of the text of the Proposal speaks to the contrary. The screening authorities will thus 'decide' to which authorities to refer the applicant and point to the elements of the border or accelerated examination procedure (Art.14(2)). At the same time the European Commission is proposing an amendment of Proposal for Asylum Procedures Regulation issued in 2016 for a more flexible use of the border procedures. It would in essence channel to the border procedure the asylum claims that are clearly abusive (misleading authorities, withholding information), constitute a security or public order threat, or concern nationalities with a low recognition rate for international protection (below 20\%). ${ }^{17}$ Would the asylum authorities need other information to channel applicants to border procedures, or could decide automatically on the basis of the screening information? Considering that border procedure could be initiated based on nationality or security information only, such screening referral could amount to automatic exclusion of low merit cases or lead to border procedures, thus would substantively affect the rights of the person. On the other hand, if the Proposal for a Screening Regulation genuinely aims to speed up the asylum procedures, then it should also either exclude from screening or prioritise referral to regular asylum procedures applicants with nationalities of high recognition rate for international protection (e.g. over $50 \%$ or so). This is regretfully overlooked by the Proposal despite some practices of the Member States and UNHCR proposals on manifestly well-founded cases. ${ }^{18}$ For instance, since the end of 2015 , Germany operates a cluster procedure in "arrival centres", ${ }^{19}$ where procedures are conducted rapidly in different clusters, including for countries of origin with a high protection rate from $50 \%$ upwards.

Furthermore, screening should be seen as contributing to the entire asylum process and cannot be assessed separately from the amended pro-

16 Explanatory Memorandum, Commission Proposal for a Regulation introducing a screening of third country nationals at the external borders, $\operatorname{COM}(2020) 612$ of 23 September $2020<$ https:/ec.europa.eu/info/sites/default/files/communication-scre ening-third-country-nationals_en.pdf $>$ accessed 15 September 2021.

17 Recital 40b, Amended Proposal for Asylum Procedures Regulation 2020.

18 UNHCR, 'Fair and Fast: UNHCR Discussion Paper on Accelerated and Simplified Procedures in the European Union'<www.refworld.org/pdfid/5b589eef4.pdf > accessed 17 September 2021.

19 ECRE, 'Accelerated, prioritised and fast-track asylum procedures. Legal frameworks and practice in Europe' (May 2017) <www.ecre.org/wp-content/uploads/20 17/05/AIDA-Brief_AcceleratedProcedures.pdf $>$ accessed 30 October 2021, 7. 
posal for the Asylum Procedures Regulation 2020, as its objective is to ensure a seamless link between border control, asylum process and return procedures. Given that decisions will be taken on the basis of screening as demonstrated above, it could be seen as promoting fast-track border procedures focusing on low recognition rate countries (easy-to-use criteria in the words of the Commission), which have been widely criticized by international organizations and courts. Such procedures are viewed as placing the applicant at serious procedural disadvantage as lawyers, NGOs and courts do not have same access to the borders as in regular procedures and might result in the underestimation of the procedural guarantees provided by international, European and national legal frameworks. The short time limits of such fast-track procedures ( 5 days) and the nature of the debriefing form (not a formal decision, information only) might undoubtedly affect the procedural guarantees available to migrants and asylum seekers at the borders. For instance, the High Court judge in the 2015 judgment ${ }^{20}$ in the UK called fast-track rules as incorporating structural unfairness. In February 2019, the Fundamental Rights Agency underlined that such fasttrack procedures substantially undermine the fundamental rights of migrants. ${ }^{21}$ The EASO report on border procedures confirms the trend that under the current legislative framework, which envisages the use of border procedures in cases that appear to have less merit, the cases channelled into the border procedure demonstrate lower recognition rates compared to regular procedures. ${ }^{22}$ The legal problems hence may result from screening, as the applicants on the basis of minimal information would be channelled to the border procedures that are based on the premise that asylum application is unfounded and where the defence possibilities for the applicant are more limited due to absence or lack of lawyers and NGOs at the borders. The Australian experiences with screening procedures and Greece practices in the hotspots demonstrate that.

In addition, as the screening may end with overall refusal of entry under Art. 14 of the Schengen Borders Code, screening would indeed result in affecting the rights of the person substantially. The Proposal for a Screening

20 'Fast-track asylum system "unlawful“, High Court rules' (BBC.com, 12 June 2015) $<$ www.bbc.com/news/uk-33113132> accessed 12 September 2021.

21 European Union Agency for Fundamental Rights, 'Update of the 2016 Opinion of the European Union Agency for Fundamental Rights on fundamental rights in the "hotspots" set up in Greece and Italy' (n 10).

22 EASO, 'Border Procedures for Asylum Applications in EU+ Countries' (European Asylum Support Office, 2020) <www.easo.europa.eu/sites/default/files/publication s/Border-procedures-asylum-applications-2020.pdf $>$ accessed 29 October 2021, 20. 
Regulation retains some degree of silence on the link to ensuring the requirements of Art. 14(2), (3) of the Schengen Borders Code, including a substantive decision by competent authorities and the right to a legal remedy. It is silent, in particular, whether that decision is to be taken in the context of the very short screening procedure or thereafter. If both were integrated, the adoption of the refusal of entry in such a short time limit without legal support to the person could lead to a risk that non-entry decisions might result in refoulement of some third country nationals. While the Proposal refers to such individuals subject to non-entry decision who did not apply for international protection, guarantees for submitting application at the border following unauthorised entry may not always be present as could be seen from some Member States' common practice that has been recently condemned by the ECtHR. ${ }^{23}$ Also, the Proposal overly relies on the legal fiction of persons being actually in the territory albeit not authorised entry during the screening process (Art. 4(1)), but it has to be made clear that this fiction would not effectively relieve Member States from their obligations under the human rights instruments or the EU Charter of Fundamental Rights ${ }^{24}$ as concerns the treatment of third country nationals within their jurisdiction. States do not have the liberty to withdraw their territorial jurisdiction due to both the nature of state territory in international law and the overarching duty to meet standards of fairness wherever there is an exercise of state power. ${ }^{25}$

23 M.K. and Others $v$ Poland App nos 40503/17, 42902/17 and 43643/17 (ECtHR, 23 July 2020); M.A. and Others v Lithuania App no 59793/17 (ECtHR, 11 December 2018).

24 Charter of Fundamental Rights of the European Union, OJ C 326/391, 26 October 2012; see also ECRE, 'Policy Note 30: Screening out rights? Delays, detention, data concerns and the EU's proposal for a pre-entry screening process. A summary of ECRE's assessment of the Screening Regulation COM (2020) 612 and its proposed amendments' (2020) <www.ecre.org/wp-content/uploads/2020/12/Polic y-Note-30.pdf $>$ accessed 27 October 2021, 3.

25 Thomas Gammeltoft-Hansen and James C. Hathaway, 'Non-Refoulement in a World of Cooperative Deterrence' (2015) 53 (2) Columbia Journal of Transnational Law $<$ https://repository.law.umich.edu/cgi/viewcontent.cgi?article=2484\& context=articles $>$ accessed on 27 October 2021, 247; See also Amuur v France App no 19776/92 (ECtHR, 25 June 1996), para 52 (international zone of airport does not have extrateritorial status, thus applicants are subject to French national law); and more recently with regard to so called "transit zones", which the Court has considered as being under the State's effective control irrespective of the domestic legal qualification - Ilias and Abmed $v$ Hungary App no 47287/15 (ECtHR, 14 March 2017), para 54. 
Thus, even if the outcome of the screening procedure will not result in a formal decision, but only in a debriefing form on the information collected, such information will be essential for the further examination of the asylum applications under the proposed Asylum Procedures Regulation or even result in a non-entry decision. Considering that the outcome of screening substantively affects the rights of the person, it may create legal problems due to its abrupt nature, lack of formal decisions and thus procedural guarantees, and leave some persons without access to protection. In this context, either such 'referral' should be formalised and subject to legal remedies, or referrals should be done immediately without screening on the basis of submission of asylum application (at least for manifestly wellfounded cases). Furthermore, even if we would consider screening as a pure collection of information, it involves collection of personal data, which requires effective remedies and could be a separate issue of discussion. ${ }^{26}$ If screening is absorbed by the asylum procedure for asylum applicants, the competent authorities would then compile the information that is necessary to objectively decide on the type of the procedures and all procedural safeguards would fully be applied. Particularly, if we consider that e.g. verification or establishment of identity or security risks during screening would be done by checking national and European databases only (Art. 10) and not employing anything new. If such option would be seen as not sufficiently addressing abuses of the procedure then we should not pretend that the screening is a pure collection of information and not a decision-making tool that may create risks of underestimation of procedural guarantees.

\section{b) Exploitation of Security Information and the ECtHR Approach}

Secondly, among the screening elements verification of risk to security is envisaged (Art. 11). However, the Proposal is not very clear as to the consequences of establishing such risk. Two possible outcomes could be envisaged. One possible outcome may be that domestic authorities are asked to adopt the decision on refusal of entry under the Schengen Borders Code if no asylum application is made (Art. 6(1)(e)). The second possible outcome

26 For an analysis on border screening processing from a right to privacy perspective in international human rights law see Elif Mendos Kuskonmaz, 'Border management and technology: a challenge to the right to privacy' in Graham Hudson and Idil Atak (eds), Migration, Security and Residence: Global and Local Perspectives (Routledge, 2021) 272. 
is based on the Amended Proposal for Asylum Procedures Regulation: the establishment of security or public order risk could serve as a basis to channel the application to the border procedures. In this respect the Member States' practice of using this information for the purpose of faster rejection of asylum applications on security grounds may be problematic with regard to Art. 19 of the EU Charter of Fundamental Rights and Art. 3 of the ECHR, as security risks cannot outweigh the protection needs according to the ECtHR when it comes to deportation, ${ }^{27}$ thus security risk information could only be used to specially deal with a person but not for the merits of the claim.

\section{c) Position of Vulnerable Persons Less Predictable?}

On the one hand the Proposal requires ensuring that special needs of the applicants are identified at early stage, ${ }^{28}$ on the other - it is not clear how these needs, if at all collected, will be channelled to the relevant authorities. The overall situation of vulnerable persons is not particularly certain in the Proposal, firstly, as concerns the identification of special needs, if compared with existing legislation. For instance, the recast Reception Conditions Directive and recast Asylum Procedures' Directive provide for mandatory ${ }^{29}$ and systematic assessment ${ }^{30}$ of vulnerability in the beginning of the procedures and throughout. While the Proposal contains a lower level of obligation to assess vulnerabilities (special needs), namely that health procedures (vulnerability assessment is part of it) may be dispensed at the border, if the relevant competent authorities are satisfied that no preliminary medical screening is necessary. ${ }^{31}$ Furthermore, the Proposal

27 Chahal $v$ The United Kingdom App no 70/1995/576/662 (ECtHR, 15 November 1996); Saadi v Italy App no 37201/06 (ECtHR, 28 February 2008); X v Sweden App no 36417/16 (ECtHR, 9 January 2018); M.K. and Others $v$ Poland App nos 40503/17, $42902 / 17$ and 43643/17 (ECtHR, 23 July 2020).

28 Art. 1, Art. 6 (6a), Art. 9 (2), (3), (4) of the Proposal.

29 Art. 22 (1) of recast Reception Conditions Directive: "That assessment shall be initiated within a reasonable period of time after an application for international protection is made and may be integrated into existing national procedures. “Also, Art. 24 (1) of recast Asylum Procedures` Directive.

30 Art. 22 (1) of recast Reception Conditions Directive: "Member States shall ensure that those special reception needs are also addressed, in accordance with the provisions of this Directive, if they become apparent at a later stage in the asylum procedure.“ Also, Art. 24 (4) of recast Asylum Procedures' Directive.

31 Art. 9 (1) of the Proposal. 
envisages that vulnerabilities or special reception or procedural needs shall be carried out only as needed or where relevant. ${ }^{32}$ This discretion left to the authorities might have an impact on persons with special needs whose vulnerabilities are not evident. Secondly, even if the obligation to identify special needs exists, it is not clear what kind of information will be collected and how this information would be channelled to further procedures, as the debriefing form - the outcome of screening, refers to immediate care needs only. ${ }^{33}$ Therefore, no clear outcome of identification of vulnerabilities' process, except provision of immediate care, is yet envisaged, and this may further weaken the standards applicable to persons with special needs, if compared with those set by current EU law.

\section{d) Inconsistencies with other Instruments on Reception Conditions}

The Proposal envisages that there is no access to Reception Conditions Directive before the screening process is completed, ${ }^{34}$ but requires that during the screening process all persons concerned should be guaranteed a standard of living complying with the EU Charter of Fundamental Rights and have access to emergency health care and essential treatment of illnesses. ${ }^{35}$ However, what the standard is, remains within national discretion. Thereby, new zones excluded from EU harmonisation seem to be created. Furthermore, this position is inconsistent with the current Reception Conditions Directive, which provides for access to reception conditions from the moment of application for international protection. ${ }^{36}$ Neither is it compatible with the proposal for a recast Reception Conditions Directive, where it was clarified that the directive applies since the wish to apply for international protection is expressed not from its registration or formal lodging, along with the interpretation by the Court of Justice of

32 Art. 9 (2) of the Proposal.

33 Art. 13 of the Proposal contains no reference to special needs at all, while annex to the Proposal refers to "immediate care" only, para 10.

34 Recital No. 16 of the Proposal reads as follows: "Article 26 and 27 of the Asylum Procedures Regulation should apply only after the screening has ended. This should be without prejudice to the fact that the persons applying for international protection at the moment of apprehension, in the course of border control at the border crossing point or during the screening, should be considered applicants."

35 Recital 27 of the Proposal.

36 Art. 17(1) of the Reception Conditions Directive. 
the European Union (hereafter CJEU) of the Asylum Procedure Directive 2013/32/EU and the recast Reception Conditions Directive 2013/33/EU. ${ }^{37}$

\section{e) Prevention of Absconding without Detention? Mission (Im)possible?}

The Proposal refers to the need to prevent absconding. The applicants will be expected to stay at the borders as they would not be considered having been authorized to enter, and will have the obligation to remain in the designated facilities during the screening. ${ }^{38}$ Despite the lack of evidence and reliable data on the scope, scale and dynamics of onward movements in the EU, the Commission opts here for introducing an obligation for Member States to hold the third country nationals - and asylum seekers in particular - at the border, by extending to air and land borders a practice already experimented with under the hotspot approach in relation to unauthorised entry by sea. ${ }^{39}$ Though Daniel Thym ${ }^{40}$ indicates that the Commission opted against generalised detention and without it being automatic, the Proposal leaves the choice of detention to the national authorities, which may spark extensive use of it for most of the applicants preventing their onward movement into the EU territory. The measures envisaged do not shed a light as to how they could prevent absconding without extensive resort to detention. As ECRE reports, in practice, Member States already use formal or de facto detention for almost all applicants when a border procedure is applied. It also warns that Member States will call this "reception" or "accommodation" leading to the worst-case scenario from a fundamental rights perspective: de facto detention with detainees deprived of the safeguards that apply in formal detention regimes. ${ }^{41}$ Just one year after the proposal was made, some

37 ECJ, Ministerio Fiscal v VL, C-36/20 PPU [2020], ECLI:EU:C:2020:495.

38 Art. 4 and 8(1)(b) of the Proposal, Art. 41(6) of the Amended Proposal for the Asylum Procedures Regulation 2020.

39 European Parliament, 'The European Commission's legislative proposals in the New Pact on Migration and Asylum' (n 4), 56.

40 Daniel Thym, 'European Realpolitik: Legislative Uncertainties and Operational Pitfalls of the "New" Pact on Migration and Asylum' (EU Migration Law Blog, 28 September 2020) <https://eumigrationlawblog.eu/european-realpolitik-legislative -uncertainties-und-operational-pitfalls-of-the-new-pact-on-migration-and-asylum/> accessed 29 October 2021.

41 ECRE, 'Policy Note 30: Screening out rights? Delays, detention, data concerns and the EU's proposal for a pre-entry screening process. A summary of ECRE's 
practices in the Member States already confirm the materialisation of such risks. ${ }^{42}$

Besides that, a question remains if the obligation to remain in facilities would amount to detention or not. This might raise some legal issues as concerns the exceptional nature of detention and the individual approach to it in international and EU law, as explored by Galina Cornelisse. ${ }^{43}$

\section{Implementation Practicalities of Proposed Measures}

According to the Proposal for a Screening Regulation, the collection of data is supposed to speed up the asylum procedure, but it is not clear how it will, as information collected in the screening would be minimal (unless this will be sufficient to abruptly reject applications in the border procedure). Although the screening procedure is supposed to last for up to 5 days at external borders (in exceptional situations to be extended to 10 days) and up to 3 days within the territory, the experience in Greece has shown that it is not realistic to meet such short deadlines. Processing of cases of third country nationals at the borders also depends on many additional factors that might delay the processes (capacities and competences of the authorities, availability of additional medical, legal, interpretation and other staff, numbers of people arriving at the borders, etc.). For instance, recent Greek experience has demonstrated that border procedures raised administrative burdens for the authorities and significantly prolonged the procedures for the applicants for asylum. Even the presence of EASO case-

assessment of the Screening Regulation COM (2020) 612 and its proposed amendments' (n 24), 3.

42 E.g., situation in Lithuania, where amendments to the legislation in summer 2021 introduced a possibility of automatic detention of migrants arriving in extraordinary situation of mass influx. Although the term "accommodation" is used, it in fact falls within the definition of detention and in practice provides for the automatic detention of asylum applicants in the event of an "extraordinary situation”, see ECRE, 'Legal Note 11: Extraordinary Responses: Legislative Changes in Lithuania, 2021. ECRE's assessment of recent changes to asylum legislation in Lithuania and their impact, with reference to compliance with EU and international law' (3 September 2021) <https://ecre.org/wp-content/uploads/2 021/09/Legal-Note-11.pdf> accessed 15 October 2021, 6.

43 Galina Cornelisse, 'The Pact and Detention: An Empty Promise of "certainty, clarity and decent conditions"' (EU Migration Law Blog, 6 January 2021) <https:// eumigrationlawblog.eu/the-pact-and-detention-an-empty-promise-of-certainty-clar ity-and-decent-conditions/> accessed 29 October 2021. 
workers in the fast-track border procedures in Greece has not prevented an average seven-month duration of the procedure between full registration and the issuance of a first instance decision, which was far beyond the two weeks envisaged by law. Another lesson from Greece was that most of the applicants were recognised as vulnerable and hence channelled to the regular asylum procedures (out of 39,505 decisions taken in 2017-2019, 25,967 persons were admitted as vulnerable), thus pre-screening in the border procedure did not make a lot of sense for making procedures faster for vulnerable individuals. ${ }^{44}$

Secondly, the Proposal for a Screening Regulation envisages the location of the screening at or in proximity to the external borders (Art. 6), which will require adjustment of the infrastructure at the border in a short term and establishment of processing centres along the borders in the long run, including the possibility of using hotspot areas. The experience in Greece has shown that despite the good intentions to process the cases in an efficient manner, there is a high risk that the persons (who will be expected to stay at the borders under a fictitious concept of not yet being authorised to enter, and will have the obligation to remain in the designated facilities during the screening) will likely accumulate at the borders, including also those who are referred to asylum procedures and likely not to be moved inside the territory (as concerns border and accelerated asylum procedures). While this could be practicable for Member States to concentrate third country nationals in one place for the purpose of return, it is questionable how these persons will be contained there likely against their will and in what conditions. The worst outcome of this regulation that everybody would like to avoid would be creating more Moria camps with complex new problems at European borders. The Proposal has ample potential for that, in particular, if we read it in combination with the solidarity and fair sharing of responsibility mechanisms. If the latter do not work, the screening and subsequent border procedures in greater migratory pressures might result in persons getting stuck in border areas. ${ }^{45}$

Thirdly, the operation of the screening process at the border would require boosting accommodation conditions and the presence of staff, including medical, legal, trained and qualified staff to deal with minors.

44 Greek Council for Refugees, 'Country Report: Fast-track border procedure (Eastern Aegean islands)' (10 June 2021) <https://asylumineurope.org/reports/country/ greece/asylum-procedure/procedures/fast-track-border-procedure-eastern-aegean/> accessed 15 October 2021.

45 European Parliament, 'The European Commission's legislative proposals in the New Pact on Migration and Asylum' (n 4), 54. 
The availability of doctors at the border areas has proved to be problematic in case of the Greek hotspots where the authorities had to rely instead on military ones. ${ }^{46}$ In times of the pandemic, the lack of doctors is very evident particularly in some countries and the feasibility to attract them to work at the borders might raise practical difficulties and thus delays.

One new element for such border procedures is the requirement of an independent monitoring mechanism for fundamental rights in relation to the screening that the Member States are required to establish as per Proposal for a Screening Regulation (Art.7). While this is a positive addition to the border procedures, generally criticized for failing to meet procedural requirements, it also poses questions as to its practicability. Such mechanism would require access to independent institutions, regular monitoring of the procedures, thus presence of lawyers, NGOs or other monitors at the borders. Such border monitoring initiatives operate in a few Member States, but they cover only a small percentage of persons at the border.

\section{Greater Role for the EU Agencies not Developed?}

Finally, the Proposal for a Screening Regulation envisages cooperation among all relevant authorities with support from EU agencies (Art. 6(7)). This part is new - except for the already tested experience with EASO involvement in asylum procedures in Greece, Italy, Cyprus and Malta ${ }^{47}$ - but remains largely unexplored as to its functionality in the Proposal. Indeed, if developed, it could serve as a sort of European task force on asylum and return, and support the authorities in ensuring swift processing and guaranteeing fundamental rights of persons at the borders. This could be particularly relevant in case of persons disembarked after search and rescue operations. Regretfully, the Commission did not pick up on the idea of the German Presidency ${ }^{48}$ that the future Asylum Agency and the European Border and Coast Guard Agency could possibly have a mandate to conduct the pre-screening independently or in support of the 'frontline' Member

46 European Union Agency for Fundamental Rights, 'Update of the 2016 Opinion of the European Union Agency for Fundamental Rights on fundamental rights in the "hotspots" set up in Greece and Italy" (n 10).

47 European Asylum Support Office, Operational Support <www.easo.europa.eu/op erational-support/types-operations $>$ accessed 28 October 2021.

48 Outline for reorienting the Common European Asylum System (13 November 2019) <www.statewatch.org/media/documents/news/2019/dec/eu-asylum-FoodFor Thought-GermanNoPaper.pdf $>$ accessed 17 October 2021. 
States. On the other hand, some international organisations observe that past experience of EU agencies' presence in rolling out national border procedures did not guarantee fairness and effectiveness. However, these experiences and learnings could contribute to setting up a more effective European support mechanism at the borders.

\section{Concluding Remarks}

In responding whether such a proposal if adopted and when implemented would reduce the numbers of migrants entering the EU, or make return procedures more effective or asylum procedures faster, the answer does not look very promising due to legal uncertainties concerning the outcomes that could undermine the rights of migrants and protection seekers. The Proposal evidently sets up some theoretical concepts, wishes and ways to optimisation of the procedures, but its practical implementation remains in doubt. Moreover, the hotspots experience has not been sufficiently considered in designing the screening procedure, because a number of rules remind of the old practices exercised in a doubtfully successful way. At the same time the proposal has a clear potential for risk of overcrowding at the borders; limited appropriate living conditions and too abrupt decisions on entry to materialise. While these issues might create more legal concerns than benefits for the entire system (including reliance on highly controversial legal fiction of non-entry), the Proposal for a Screening Regulation needs to be seen in a broader context of promoting border and accelerated procedures in the Commission's asylum and migration package.

Even if nothing is wrong in collecting the information on third country nationals entering the EU as early as possible, the question remains if a separate instrument is needed for that. Such information gathering is happening already now and provisions on improving it could be incorporated in both asylum and return procedures by amending the Schengen Borders Code, the proposal for Asylum Procedures Regulation, the proposal for recast Return Directive ${ }^{49}$ and other relevant instruments.

49 Proposal for a Directive of the European Parliament and of the Council on common standards and procedures in Member States for returning illegally staying thirdcountry nationals (recast), A contribution from the European Commission to the Leaders' meeting in Salzburg on 19-20 September 2018, COM/2018/634 final $<$ https://eur-lex.europa.eu/legal-content/EN/TXT/?uri=CELEX:52018PC0634> accessed 30 October 2021. 
The pre-entry screening seems to set the basis for the operation of these procedures by re-decorating some existing practices under a new merger of procedures, but without addressing the core issues at stake. The attempt in the Proposal to ensure a seamless link between the asylum and return procedures reflects not a novelty, but rather an embedment of some Member States' practices that reflect on a potential shift of a paradigm of asylum procedures. If we really want to diversify the flows at the border and optimise the process then, as a minimum, screening of manifestly-founded cases into asylum procedures immediately would be one of the solutions that could be practically realised, as well as more active engagement of the EU agencies in procedures at European borders thereby leaving less discretion to the Member States to deviate in their approach, as these deviations cannot bring a better result for the entire EU. 
